\title{
Genetic mapping of a modifier locus affecting hypertension in soluble guanylate cyclase $\alpha_{1}$ deficient mice
}

\author{
Emmanuel S Buys ${ }^{1 *}$, Michael J Raher ${ }^{1}$, Andrew Kirby² ${ }^{2}$ Sarah R Hayton ${ }^{1}$, Laurel T Tainsh ${ }^{1}$, Patrick Y Sips ${ }^{1}$, \\ Peter Brouckaert ${ }^{3}$, Mark J Daly², Kenneth D Bloch ${ }^{1}$ \\ From 5th International Conference on cGMP: Generators, Effectors and Therapeutic Implications \\ Halle, Germany. 24-26 June 2011
}

\section{Background}

We previously reported that male mice deficient in the $\alpha_{1}$ subunit of the NO receptor soluble guanylate cyclase (sGCa ${ }_{1}^{-1-}$ mice), an important nitric oxide (NO) receptor, are hypertensive [1]. The phenotype depends on the genetic background: $\mathrm{sGC}_{1}{ }^{-1-}$ mice on a $129 \mathrm{~S} 6$ (S6) background $\left(\mathrm{sGC}_{1}{ }^{-1-\mathrm{S} 6}\right)$ but not on a C57BL/6 (B6) background

$\left(\mathrm{sGC}_{1}{ }^{-/-\mathrm{B} 6}\right)$ develop hypertension [2]. These findings suggest that hypertension associated with $\mathrm{sGC} \alpha_{1}$-deficiency is modulated by genetic factors. We aimed to identify modifier genes underlying the hypertension in $\mathrm{sGC} \alpha_{1}^{-1-\mathrm{S} 6}$ mice.

\section{Materials and methods}

Mean arterial blood pressure (MAP) was measured invasively in 280 male $\mathrm{F} 2$ offspring from a sGC $\alpha_{1}^{-1-\mathrm{S} 6}$ $\mathrm{X} \mathrm{sGC \alpha}{ }_{1}^{-/-\mathrm{B} 6}$ intercross $\left(\mathrm{sGC}_{1}{ }^{-/ \mathrm{F} 2}\right)$. All mice were genotyped with a genome-wide panel of 150 SNP markers for linkage analysis using the Sequenom MassArray system and MAPMAKER/QTL. Renin-1c and renin-2d genotyping was performed using gene-specific primers. Plasma renin activity (PRA) and aldosterone were measured in anesthetized male S6 wild-type $\left(\mathrm{WT}^{\mathrm{S} 6}\right)$ and $\mathrm{sGC} \alpha_{1}^{-1-\mathrm{S} 6}$ mice by radioimmunoassay and enzyme-linked immunoassay, respectively. The renin angiotensin system (RAS) was blocked by treating mice with either the aldosterone receptor antagonist, Spironolactone $(100 \mathrm{mg} / \mathrm{kg} /$ day, subcutaneous pellet for

\footnotetext{
* Correspondence: ebuys@partners.org

'Department of Anesthesia Critical Care and Pain Medicine, Massachusetts General Hospital, Boston, MA, USA

Full list of author information is available at the end of the article
}

7 days), or the renin inhibitor, Aliskiren $(200 \mathrm{mg} / \mathrm{kg} /$ day, by gavage for 10 days).

\section{Results}

MAP in $\mathrm{sGC \alpha}_{1}{ }^{-/-\mathrm{F} 2}$ mice varied between values observed in $\mathrm{sGC} \alpha_{1}^{-1-\mathrm{S} 6}$ and $\mathrm{sGC} \alpha_{1}^{-1-\mathrm{B} 6}$ mice. Linkage analysis identified a locus on chromosome 1 with a highly significant logarithm of odds (LOD) score of 6.1. This region is syntenic with previously identified hypertensionrelated QTLs in the human and rat genome and contains the gene coding for renin. Importantly, B6 mice have one renin gene (renin-1c), and S6 mice have two renin genes (renin-1d and renin-2). Presence of the renin-1d and renin-2 genes correlated significantly with elevated MAP in the F2 mice $(\mathrm{P}<0.0001)$. PRA was higher in $\mathrm{sGC \alpha}_{1}{ }^{-1-\mathrm{S} 6}$ than in $\mathrm{WT}^{\mathrm{S} 6}$ mice $(0.29 \pm 0.01$ vs. $0.23 \pm 0.03 \mu \mathrm{g}$ angiotensin $1 / \mathrm{ml} / \mathrm{hr}$, respectively, $\mathrm{P}<0.05$ ). Similarly, plasma aldosterone levels were higher in $\mathrm{sGC}^{-1-\mathrm{S} 6}$ than in $\mathrm{WT}^{\mathrm{S} 6}$ mice $(0.47 \pm 0.03$ vs $0.34 \pm 0.03$ $\mathrm{ng} / \mathrm{ml}$, respectively, $\mathrm{P}<0.05)$. Treatment with Spironolactone or Aliskiren normalized blood pressure in $\mathrm{sGC}_{1}{ }^{-1-}$ S6 ( $117 \pm 5$ vs $146 \pm 2 \mathrm{mmHg}$, in Spironolactone and vehicle-treated mice, respectively, $\mathrm{P}<0.001$, and $100 \pm 7$ vs $148 \pm 4 \mathrm{mmHg}$, in Aliskiren and vehicle-treated mice, respectively, $\mathrm{P}<0.001$ ).

\section{Conclusion}

Together, these data identify renin as a possible genetic modifier of blood pressure in a setting of deficient NOcGMP signaling. Furthermore, these findings highlight the importance of sGC in the regulation of the reninangiotensin system (RAS) and suggest that sGC may be a therapeutic target in RAS-dependent hypertension. 


\section{Author details}

'Department of Anesthesia Critical Care and Pain Medicine, Massachusetts General Hospital, Boston, MA, USA. ${ }^{2}$ Department of Medicine, Center for Human Genetic Research, Massachusetts General Hospital, Boston, MA, USA

${ }^{3}$ VIB Department of Molecular Biomedical Research, Ghent University, Ghent, Belgium.

Published: 1 August 2011

\section{References}

1. Buys ES, Sips P, Vermeersch P, Raher MJ, Rogge E, Ichinose F, Dewerchin M, Bloch KD, Janssens S, Brouckaert P: Gender-specific hypertension and responsiveness to nitric oxide in $\mathrm{sGCa}_{1}$ knockout mice. Cardiovasc Res 2008, 79:179-186.

2. Buys ES, Cauwels A, Raher MJ, Passeri JJ, Hobai M, Cawley SM, Rauwerdink KM, Thibault H, Sips PY, Thoonen R, Scherrer-Crosbie M, Ichinose F, Brouckaert P, Bloch KD: sGCa $\beta_{1}$ attenuates cardiac dysfunction and mortality in murine inflammatory shock models. Am J Physiol 2009, 297:H654-663.

doi:10.1186/1471-2210-11-S1-P14

Cite this article as: Buys et al: Genetic mapping of a modifier locus affecting hypertension in soluble guanylate cyclase $\alpha_{1}$ deficient mice. BMC Pharmacology 2011 11(Suppl 1):P14.

\section{Submit your next manuscript to BioMed Central} and take full advantage of:

- Convenient online submission

- Thorough peer review

- No space constraints or color figure charges

- Immediate publication on acceptance

- Inclusion in PubMed, CAS, Scopus and Google Scholar

- Research which is freely available for redistribution

Submit your manuscript at www.biomedcentral.com/submit
Ciomed Central 